\title{
The 2000 EU water framework directive and Chinese water management: experiences and perspectives
}

\author{
W. Ravesteijn ${ }^{1}$, X. Song ${ }^{2} \&$ R. Wennersten ${ }^{2}$ \\ ${ }^{I}$ Department of Technology Dynamics \& Sustainable Development, \\ Delft University of Technology, The Netherlands \\ ${ }^{2}$ Department of Industrial Ecology, \\ Royal Institute of Technology, Sweden
}

\begin{abstract}
This paper addresses Integrated River Basin Management as a solution to water stress through a comparative analysis of water management in Europe and China. It makes a preliminary assessment of the European experiences so far with the Water Framework Directive (WFD) on river basin management and investigates its potential value for other areas, focusing on China. Problems and possibilities of policy transfer in the process of initiating and stimulating sustainable water management are investigated. Could the WFD, which seems to have beneficial impact in Europe, be used to reach the same results in China? We will deal with this and other questions, discussing the differences in water management and context between China and the EU and the problems with adopting a WFD inspired approach in China.
\end{abstract}

Keywords: China, European Union, Integrated River Basin Management, Water Framework Directive, policy transfer.

\section{Introduction}

Water stress, including water scarcity, large-scale flooding and high-level contamination of drinking water, is a serious problem in the world of today in which regions, countries and localities experience different problems - or mixtures of problems - in different levels of severity. Flooding, e.g., threatens delta areas, while drought threatens many inland areas. Global warming aggravates these problems, including the introduction of new types of problems 
like flood hazards to complete delta areas, which could entail not only direct human suffering but also lead to local and international conflicts about the availability, distribution and risks of scarce water resources.

It has long been accepted that a socio-technical systems approach is critical to address water management problems and to generate solutions [1-5]. Balancing the interests of different water using sectors and different actors, combining arrangements and decisions at different scales, and linking communities to their physical resource base are seen as prerequisites for sustainable development. All of these issues can only be addressed from a systems perspective, focusing on the interactions and relations between the various components, rather than treating them as isolated issues as well as considering the dynamics of the systems themselves. Integrated River Basin Management (IRBM) - like Integrated Water Resources Management (IWRM) - clearly builds on a systems approach to water resources management and, consequently, it is a promising tool for dealing with present-day water stress.

This paper addresses IRBM through a comparative analysis of water management in Europe and China. It focuses on the European version of IRBM: the Water Framework Directive (WFD), and investigates its relevance for China. Questions dealt with are: Is the WFD appropriate and feasible in the Chinese context? What would be the implications of introducing the WFD for Chinese water management? What adaptations might be necessary? How would context and adaptations influence the potential benefits of the WFD? First, we will enter into the European WFD and its backgrounds. Consequently, we will describe and analyze the water problems and policies in China. Last but not least, we will discuss the possibilities and limitations of policy transfer from Europe to China.

\section{European WFD}

Water resources management and development have a long history in Europe. Trans-boundary rivers like the Rivers Rhine and Danube required conflict management for a long time, while the post-war rapid economic growth affected river systems and called for intervention too. Water-related legislation has been developed since the 1970s with various aims, e.g. reducing emissions of certain substances from different sources and water quality objectives for drinking water and bathing. During the early 1990s, however, needs emerged to address water management challenges from a more integrated and holistic perspective. In December 2000, the Water Framework Directive (WFD) was issued after long time cross-national negotiation and implemented in all 25 EU member states.

The main objectives of the WFD are:

- Expanding the scope of water protection to all waters (inland surface waters, transitional water, coastal waters and groundwater) in a holistic way

- Achieving "good status" for all waters by the target date of 2015, satisfying human needs, ecosystem functions and biodiversity protection

- Water management within the hydrological/geographical boundaries of river basins via effective cooperation of all administrations and institutions involved 
- "Combined approach" towards the control of both point and non-pointed pollutant sources with emission limit values and water quality standards

- Getting the right prices of water with the elements of cost recovery and costeffectiveness provisions

- Getting citizen more closely involved in river basin management activities

- Streamlining legislation by repelling existing fragmented and burdensome regulatory systems [6].

The European WFD provides a common framework for water policy employing integrated approaches and innovative instruments to water management. It was developed as a response to the fragmented European environmental legislation. However, the international cooperation concerning the Rhine, starting in the nineteenth century, can be considered a pioneering effort. The WFD offers a policy frame for protecting and improving the quality of water resources, though it also involves flood and groundwater quality control. It provides for cooperation at the level of river basins. A precise planning procedure for river basin management is part of it (fig. 1).

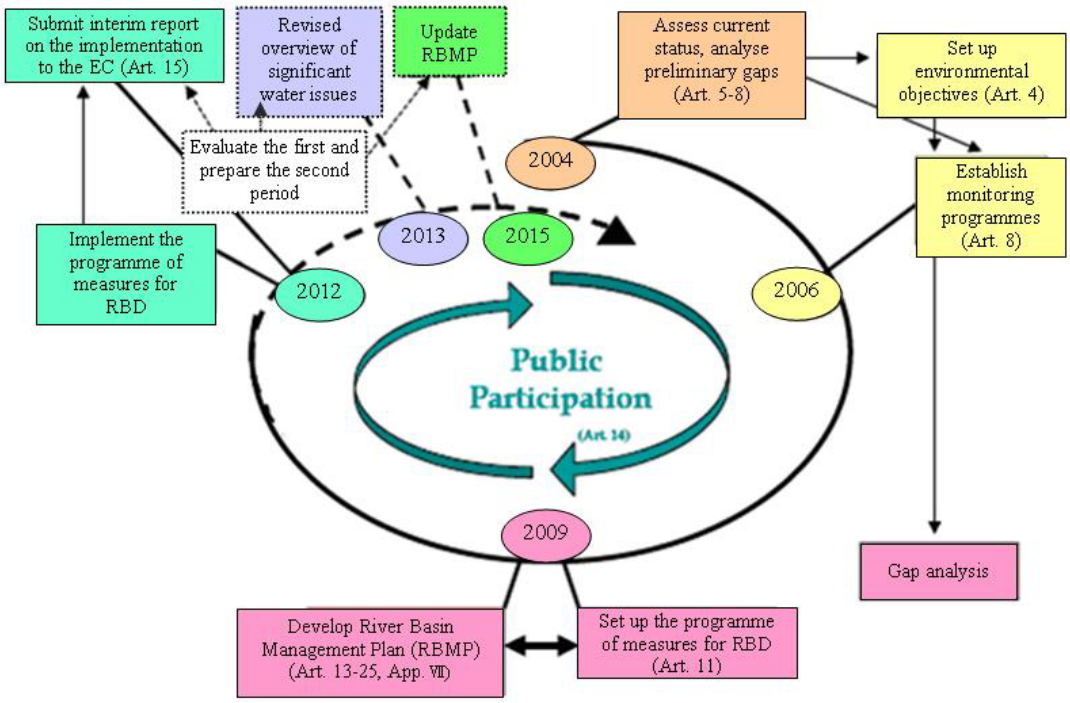

Figure 1: $\quad$ River basin management planning process [8].

The main point is towards water resources management at river basin level in districts. These River Basin Districts (RBD's) are largely based on surface water catchments, together with the boundaries of associated groundwater and coastal water bodies. In April 2009, the conference of "Active involvement in River Basin Management - Plunge into the debate!" in Brussels has supported the preparation of river basin plans [7].

The WFD is the European edition of IRBM, stimulated and being conditioned by the post-war European unification process, in which public control measures follow on the establishment of a free market. The concept of IRBM comprises 
multi-purpose water projects, basin wide programs and comprehensive regional development. It has been created in the United Stated of America in the first half of the twentieth century on the basis of engineering and management experiences from all continents [4]. In fact, IRBM being a management tool strongly reflects the doctrines of planning, which originated from the Second Industrial Revolution taking place in Germany and the USA. Planning procedures were part of Roosevelt's New Deal politics (e.g. the Tennessee Valley Authority), but became a dominant policy instrument first in the Soviet Union. After the Second World War, planning as part of management became widely adopted. Similarly, IRBM has been broadly accepted as a framework for water policy, in which water developers often combine modern concepts with endogenous water traditions. The European WFD is a case in point.

The EU WFD reflects many but not all the elements of IRBM, though tailored to the specifics of the European countries. Though it is causing tensions here and there in view of national water traditions [9], in general, the WFD seems to work quite well; the goals at least - in 2015 all waters in a "good condition" - are still within reach. However, recent assessments point out that at least $40 \%$ of the European water bodies are "at risk" not meeting the goal [10]. Nevertheless, the WFD has been hailed as a front runner on integrated water management in the world owing to the introduction of a number of generally agreed principles and concepts into a binding regulatory instrument [11].

Consequently, it has become a source of inspiration for water management reforms elsewhere, most notably in China where the authorities have shown interests in adopting the WFD to fight the river pollution problems they are experiencing, e.g. in the cases of the Yellow River and Yangtze River.

\section{Chinese water management}

There are four main water problems in China: water pollution, water scarcity and droughts, frequent floods and degradation of aquatic environments. River pollution becomes more and more serious: annual domestic and industrial wastewater discharge has increased from 23.9 billion $\mathrm{m}^{3}$ in 1980 to 68 billion $\mathrm{m}^{3}$ in 2003 [12]. Around $30 \%$ of the rivers are seriously polluted.

Water uses competitions are gradually intense among agriculture, industry and municipality due to rapid urbanization, industrialization and sustained population growth. National water consumption in 2007 was 581.9 billion $\mathrm{m}^{3}$, of which $12.2 \%$ for domestic water use, $24.1 \%$ for industry and $61.9 \%$ for agriculture [13]. Moreover, various trans-jurisdictional conflicts are emerging, e.g. on water rights and water pollution.

\subsection{Laws}

China has developed a set of water relevant laws and regulations since the 1980s, including the Prevention and Control of Water Pollution Law (1984, amended in 1996 and 2008), the Regulations for River Administration (1988), the Environmental Protection Law (1989), the Water and Soil Conservation Law 
(1991), and the Flood Control Law (1998). The main law, however, is the Water Law, initiated in 1988 and amended in 2002.

After some 10 years of preparation and discussion, the first Water Law was issued in 1988 for the purposes of rational water resources development and protection as well as water disaster control and prevention. It marks China's water management shift from "administrative management" to "water governance by law". The state is owner (Article 3) and "shall exercise a system of unified administration on water resources in association with administration at various levels and by various departments" (Art. 9). Since water pollution only took place in the northern areas, regulations on water resources protection were weak. Moreover, there was no explicit provision for IRBM.

The amended Water Law was issued in 2002. Its purposes are to promote rational development, sustainable utilization and effective protection of water resources in a way contributing to national economic and social development (Art. 1). The highest priority is meeting the needs of both urban and rural inhabitants, while taking into accounts the needs of agriculture, industry, environment and navigation (Art. 21). To achieve these targets, comprehensive planning should be employed (Art. 4). The state should formulate strategic plans for national water resources on the basis of river basin and administrative regions (Art. 14). Moreover, river basin plans were distinguished from administrative regional plans, the latter officially subordinate to the former (Art. 15).

\subsection{Institutional structure}

China has a long history of river basin development and management in various forms, including the establishment of seven river basin commissions (RBCs) since the 1930s and consequent attempts to develop river basin plans. RBCs primarily focused on traditional hydropower and flood control projects. From the 1980s, rapid economic growth caused serious river pollution in the north and pollution prevention at river basin level got increasing attention. Present river basin development was initiated by the 2002 Water Law, which provides a combined system of river basin management and administrative water resources management (Art. 12). The administrative departments for water resources under the State Council are responsible for unified water management and supervision, while river basin authorities have to perform the management and supervision duties. RBCs, however, have a weak position with regard to river basin planning, development and management as well water conflicts resolutions. Water conflicts among administrative regions, e.g., ultimately have to be judged by higher level government authorities (Art. 56).

One of the main problems with river water management is the separate management of water quantity and water quality, carried out by the Ministry of Water Resources (MWR) and the Ministry of Environmental Protection (MEP) respectively (fig. 2). The MWR is responsible for water resources protection, water allocation, monitoring, flood prevention and water conservation, while water pollution prevention, water environmental quality management and information release are the responsibilities of the MEP. The Water Protection Bureau of the RBCs, assisting in water quality management, is led by the MEP 


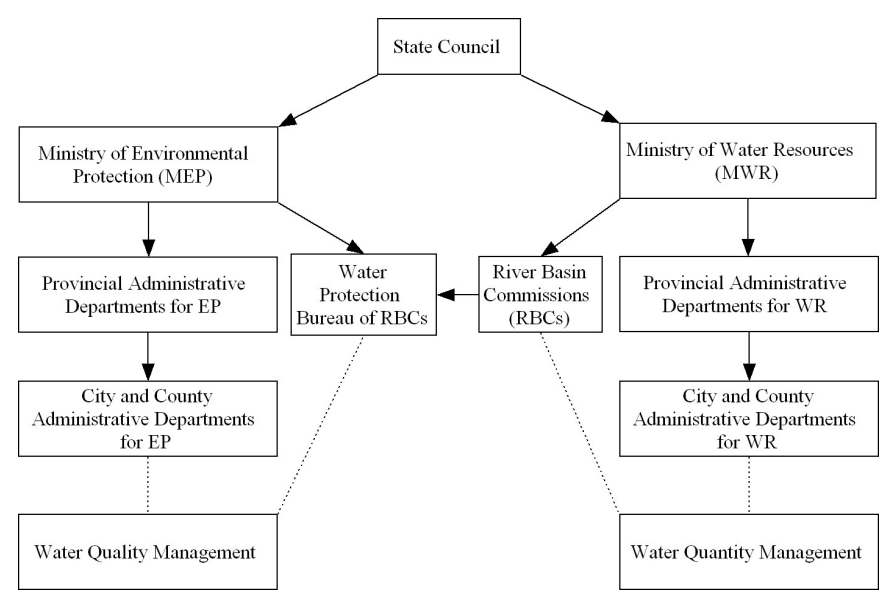

Figure 2: Separate water quality and quantity management in China.

as well as the MWR. Actually, the core of current river basin management is flood prevention and, consequently, it is very hard for RBCs to react and take measures promptly after large scale water pollution at river basin level.

\subsection{IRBM}

Though the concepts of sustainable development are gradually becoming prominent in China, water management policy and practices towards IWRM and IRBM remain out-of-date and fragmented. The awareness grows, however, that comprehensive water resources development and management at river basin level is crucial to improve the current water situation and to ensure the long-term availability of water resources as a base of social welfare [14]. Problems to overcome include weak water governance, low level of public participation, inefficient implementation of laws and regulations and overlapping legal and institutional functions. IRBM/IWRM based water reforms are necessary and should include strengthening and improving the legal position of RBCs, water demand management, pollution control and prevention, balanced hydroecological system protection and economic development, coordination with regard to laws, regulations and institutions as well as appropriate planning and decision-making procedures. International IRBM experiences, e.g. with the EU WFD, could help China in regard to the legal and institutional framework, conflicts resolution and management instruments.

\section{Discussion}

IRBM has attracted attention from both developed and developing countries in addressing present-day water stress. Valuable lessons can be learned from experiences with applications like the EU WFD. However, policy transfer is far from easy. Hooper $[15,16]$ argues that south-south exchange of experiences is 
more likely to promote effective IRBM implementation than north-south dialogue, partly because of divergent basin realities. Attempts to use the MurrayDarling model in Vietnam and China have encountered serious problems [17]. These cases show that river basin management strategies must be adapted to local situations and that institutional water reforms in developing countries cannot result from duplicating management in developed countries. Does this also hold for implementing the WFD in China? Could the WFD, as an IRBM example, be adopted in China, having the same beneficial effects as in Europe?

China is facing major challenges in managing its scarce water resources to sustain economic growth and it makes tremendous attempts to fight water stress with elements from foreign water approaches, including IWRM methods. Some researches and activities have been carried out in order to find and assess learning possibilities, involving e.g. water management in Austria [18], the EU and USA [19] as well as the International Yellow and Yangtze River Forum. The WFD inspired the EU-China River Basin Management Programme (2007-2012, focussed on the Yellow River and Yangtze basins [20]).

In order to answer the above questions, there are some facets to take into consideration, including differences and similarities between China and Europe and the water situation in both regions [21]. Table 1 gives an overview of differences in water management in the EU and China, reflecting differences as to the specific water stress situation, both physically and perceived, development status, policy priorities as well as the broader socio-economic, politicaleconomic and socio-cultural context and historical backgrounds.

Table 1: Comparison of contemporary water management between EU and China.

\begin{tabular}{|c|c|c|}
\hline Aspect & $\mathbf{E U}$ & China \\
\hline Objectives & $\begin{array}{l}\text { Good water status } \\
\text { (surface and groundwater) }\end{array}$ & $\begin{array}{l}\text { Water conservation and pollution } \\
\text { prevention }\end{array}$ \\
\hline $\begin{array}{l}\text { Scope of } \\
\text { planning }\end{array}$ & $\begin{array}{l}\text { River basin planning, update river } \\
\text { basin plan every six years }\end{array}$ & $\begin{array}{l}\text { Combination of river basin planning } \\
\text { and regional administrative planning }\end{array}$ \\
\hline $\begin{array}{l}\text { Pollutants } \\
\text { management }\end{array}$ & $\begin{array}{l}\text { Combined approach towards control } \\
\text { of both point and non-point pollutant } \\
\text { sources }\end{array}$ & $\begin{array}{l}\text { Mainly control of point source } \\
\text { pollution, no effective measures for } \\
\text { non-point source pollution }\end{array}$ \\
\hline $\begin{array}{l}\text { Decision } \\
\text { making }\end{array}$ & $\begin{array}{l}\text { Top-down and bottom-up, } \\
\text { centralized and decentralized } \\
\text { management }\end{array}$ & Top-down, centralized management \\
\hline $\begin{array}{l}\text { Water } \\
\text { allocation and } \\
\text { water rights }\end{array}$ & $\begin{array}{l}\text { Controls on water abstraction and } \\
\text { groundwater recharge; member } \\
\text { states' own policies specify water } \\
\text { rights }\end{array}$ & $\begin{array}{l}\text { Rational allocation; ambiguous water } \\
\text { rights }\end{array}$ \\
\hline Water pricing & $\begin{array}{l}\text { Full cost recovery and cost-effective } \\
\text { provisions to be taken into account }\end{array}$ & $\begin{array}{l}\text { Preliminary research on water price, } \\
\text { its components, and measurement }\end{array}$ \\
\hline $\begin{array}{l}\text { Public } \\
\text { participation }\end{array}$ & $\begin{array}{l}\text { Getting citizen more closely involved } \\
\text { in river basin management activities }\end{array}$ & $\begin{array}{l}\text { Insufficient stakeholder participation } \\
\text { and limited water-related scope }\end{array}$ \\
\hline
\end{tabular}

The differences in water management as well as the social, economic, political and cultural differences between the EU and China seem to preclude complete importation of the WFD. Three points deserve attention. 
1. A striking difference is the political structure as well as political tendencies, which determine developments and possibilities in the water domain. Presently in China, central guidance in water management to address the varied and complex water problems is getting more and more difficult, which implies the necessity of exploring combined central and decentral strategies to be explored. The European case offers an interesting example in this respect, though the other way around: Europe is moving toward increased central guidance in a basically decentralized (nationally organized) social system, whereas China tries to adopt decentral elements in its water management approaches in order to solve complex water administrative problems. China and Europe are representing two archetypal organizational models for implementing IRBM, i.e. the authority model and the coordination and negotiation model. Interestingly, however, a tendency to convergence can be noted.

2. It makes sense to manage rivers in regard to hydrological boundaries. Consequently, river basin administrations are considered to be of essential importance in both China and Europe. The problem, however, is how the distribution of power among river basin administrations and administrative agencies should be arranged. China definitely needs rivers to be fully managed and developed in terms of complete basins as Europe presently strives after, but the question remains how to transform the actual RBCs framework in this direction.

3. The involvement of local stakeholders in basin-level planning and actions was right from the start a main point in Europe, logically related to the political organization of decision-making and policy implementation in Europe. The April 2009 Active involvement in River Basin Management conference in Brussels exemplifies this. It brought decision-makers and stakeholders from all across Europe together in view of the formulation and publication of river basin plans before 2010 [7]. How to realize such in present-day China? In general, China's progress in realizing IRBM depends on the public awareness of environmental problems in relation to economic growth as well as the development of a civil society.

China's legislation on IRBM does not provide clear guidance on how to achieve it. The EU WFD can be used as an example. Theoretically, the European approach is helpful for China with regard to alleviating river pollution and ecological degradation. However, the contextual differences on hydrology, water stress, legal and institutional structure and the like clearly indicate that WFD can not be applied directly to China.

\section{Conclusion}

The experiences with the WFD are far-reaching and relevant beyond the scope of Europe. It changes the widely held view that water resources primarily serve economic development. Furthermore, it puts forward a series of management facets, e.g. clear and effective water legislation, public participation, water management on hydrological boundaries and cost recovery, which offer potential 
lessons for the development of integrated river management elsewhere. Consequently, the WFD - as an example of IRBM - has attracted foreign attention, most notably from the Chinese water authorities.

Controlling rivers has been the main priority in China's traditional "hydraulic society", especially involving dam construction and long distance water diversion. Although water management strategies have shifted from "water engineering" to an approach of managing and developing "water resources" in the 1990s, more adaptive strategies towards IWRM and IRBM in China are necessary for fighting the massive river pollution and other water problems.

However, there are large differences in the scope and scale of water management as well as in the social, economic and cultural context between the EU and China, which seem to preclude the complete importation or 'transplantation' of the WFD. Furthermore, the WFD is very complex and requires a lot of (inter)national cooperation. The implication for China is that pure legislative and institutional reforms do not suffice. The water management agencies should get full opportunity to supervise integrated water resources planning and management, enforce water laws effectively and promote public participation at all different levels.

Nevertheless, experiences with the WFD can have some implications as to the implementation of river basin management in China. Given all the water management aspects it introduced and systemized, the WFD could be employed as a reference case to facilitate the development of effective river basin management systems in China in the long term, taking into account the river basin diversity, as well as China's social, environmental and economic development.

\section{References}

[1] Ravesteijn, W., Hermans, L. \& Vleuten, E. van der, Water systems: Participation and globalisation in water system building. Knowledge, Technology \& Policy 14(4), pp. 4-12, 2002 (special issue).

[2] Bressers, H. \& Kuks, S. (eds.), Integrated Governance and Water Basin Management, Kluwer Academic Publishers: Dordrecht/Boston/London, 2004.

[3] Kaijser, A., System building from below: Institutional change in Dutch water control systems. Technology and Culture 43(3), pp. 521-548, 2002.

[4] Kates, R.W \& Burton, I. (eds.), Geography, Resources and Environment. Vol. 2: Themes from the Work of Gilbert F. White, The University of Chicago Press: Chicago, 1986.

[5] Hoekstra, A.Y. \& Huynen, M., Balancing the world water demand and supply (Chapter 2). Transitions in a Globalising World, eds. P. Martens \& J. Rotmans, Swets \& Zeitlinger Publishers: Lisse, pp. 17-35, 2002.

[6] European Commission (EC), Introduction to the new EU Water Framework Directive, http://ec.europa.eu/environment/water/waterframework /overview.html, 2000. 
[7] European Water Conference (EWC), http://ec.europa.eu/environment /water/index_en.htm, 2009.

[8] Europe Environmental Agency (EEA), River basin management plans and programme of measures, http://www.eea.europa.eu/themes/water/watermanagement/themes/water-management/river-basin-management-plansand-programme-of-measures (accessed on April 11, 2009).

[9] Ravesteijn, W. \& Kroesen, O., Tensions in water management: Dutch tradition and European policy. Water Science \& Technology 56(4), pp.105-111, 2007.

[10] European Commission (DG Environment), Water note no. 2, Wise 2008 ec.europa.eu/environment/water/water-framework/pdf/water_note2 cleaning_up.pdf, 2008.

[11] Commission of the European Communities (CEC), Towards Sustainable Water Management in the EU; First stage in the implementation of the Water Framework Directive 2000/60/EC, Brussels, 2007.

[12] Lee, S., China's Water Policy Challenges. Discussion Paper 13, China Policy Institute, University of Nottingham, Nottingham, 2006.

[13] Ministry of Water Resources (MWR), China Water Resources Bulletin (in Chinese), http://www.mwr.gov.cn/xygb/szygb/qgszygb/index.aspx, 2007.

[14] Song, X, Wennersten, R., Assefa, G. \& Ravesteijn, W., Managing water resources for sustainable development: The case of integrated river basin management in China. Proceedings of the IWA Conference on Industrial Water Treatment Systems, 2 and 3 October 2008, Amsterdam RAI, the Netherlands (CD-ROM), 2008.

[15] Hooper, B., Integrated River Basin Governance: Learning from International Experience. IWA, London, 2005.

[16] Hooper, B., Integrated water resources management: Governance, best practice, and research challenges. Journal of Contemporary Water Research \& Education 135, pp. 1-7, 2006.

[17] Svendsen, M., Integrated management of water in river basins (Chapter 13). Overcoming Water Scarcity and Quality Constrains, eds. R.S. Meinzen-Dick \& M.W. Rosegrant, 2020 Vision Focus No. 9, International Food Policy Research Institute, Washington D.C., pp. 26-27, 2001.

[18] $\mathrm{Hu}, \mathrm{X}$., Integrated catchment management in China: Application of Australian experiences. Water International, 24(4), pp. 293-306, 1999.

[19] World Bank, Evolution of Integrated Approaches to Water Resource Management in Europe and the United States. World Bank Analytical and Advisory Assistant Programme, Background Paper No.2, 43 pp., 2006.

[20] Wang, Y., Li, L., Wang, X., Yu, X. and Wang, Y., Taking Stock of Integrated River Basin Management in China, Science Press: Beijing, 2007.

[21] Jong, M.D., Lalenis, K. \& Mamadouh, V., The Theory and Practice of Institutional Transplantation: Experiences with the Transfer of Policy Institutions, Kluwer Academic Publishers, The Netherlands, 2002. 